\title{
Computer Science Students' Perceptions of Mobile Technology in the Classroom
}

\section{DB Jordaan}

\author{
North-West University, Faculty of Economic Sciences and Information Technology \\ PO Box 1174, Vanderbijpark, 1900, Republic of South Africa \\ Email: Dawid.Jordaan@nwu.ac.za
}

\author{
Doi:10.5901/mjss.2014.v5n21p353
}

\begin{abstract}
Technology has become an essential part of society. It is not hard to imagine a technology-rich classroom where students use mobile technology to search the web, complete assignments, assess progress, create projects, and help each other solve problems. Students' perceptions towards the use of mobile technology with image-rich interfaces in the classroom may be critical in establishing appropriate interventions to help lecturers integrate these resources into teaching and learning situations. The purpose of this research was to identify the perceptions of computer science students towards mobile technology in the classroom. A quantitative research approach involving the administration of a structured questionnaire to computer science students was used to collect data for the study. The questionnaire included questions on demographics and attitudes about mobile technology in class. The study revealed that computer science students have a positive attitude towards the use of technology in class and realise the potential benefits of using mobile technology in class. It is clear from the results that the use of laptops and tablets in class are preferred to that of mobile phones, as the response with regard to the latter was less favourable.
\end{abstract}

Keywords: mobile technology, computer science students' perceptions

\section{Introduction}

In many countries the industrial-era model of education, wherein a teacher uses a narrow set of resources to lecture to students for a set period of time, persists in schools (Johnson, 2012). The real world no longer works this way and the education model - the classroom in particular - should be transformed to reflect the modern workplace and take into account the technology experiences of the learners.

Graduates from schools and universities should be creative, critical thinkers, team workers and equipped with problem-solving skills (Resnick, Maloney, Hernández, Rusk, Eastmond, Brennan, et al., 2009), as many of them will enter into jobs that have not yet been created (Johnson, 2012). The ideal situation would be that these skills are learned in schools and universities using the same technology that business experts use every day. Students need a conducive, creative and challenging classroom environment to which they can relate and have a positive impact on their career preparation (Kurkovsky, 2009). Activities involving mobile technologies have the potential to allow all students to succeed, develop positive attitudes towards one another, and realise the value of working with others (Stables, 1997. Students need an environment where there are opportunities to work on challenging activities with the chance to succeed, and where it is safe for them to take risks and experience failure (Stables, 1997).

Technology is used in almost every sphere of our lives - by academic institutions and government, as well as in the fields of business, medicine and science - and has become an essential part of society. To incorporate the use of technology in education is now more important than ever before. Rodgers $(2014$, p. 1) makes the following observation, "Imagine a classroom where everyone uses a smartphone, laptop, tablet, or other mobile device to search the web, complete assignments, assess progress, create projects, and help each other solve problems." The latest technologies may be used to learn new things in new ways - students can, for example, use the video capability on their mobile devices to record presentations which they can then post to shared blogs for everyone in their network to see. Their devices may accompany them to after-school activities where they can continue working on projects and homework, and contact each other or their lecturer.

Regrettably, mobile technology is not used as well as it could be in class. Rather than being used as a learning tool, mobile phones are sometimes perceived as a distraction in class and many lecturers require students to put their mobile phones on silent when attending class. In some cases schools even ban mobile phones during classes (Seng, 2013). At Nan Chiau Primary School (NCPS), however, grade three students are free to take photos and record videos 
during class time using their smart phones to help them remember what they have learned (Seng, 2013). Johnson (2012, p. 1) remarks that, "If implemented correctly, the use of always-on, always-connected mobile devices can dramatically improve student success by providing unprecedented access to learning resources and the ability to collaborate with peers and advisers in and out of the classroom."

\section{Rationale for the Study}

A national study by Noel-Levitz, OmniUpdate, CollegeWeekLive, and the National Research Center for College and University Admissions, which surveyed 2,000 high school students, found that 68 percent of students use mobile devices to access university websites (PRWeb, 2013). The same study revealed that 43 percent go online almost exclusively using their mobile devices, 50 percent prefer university websites that are adapted to mobile displays, and 73 percent are interested in universities where mobile applications are offered. From these findings and the rapid growth of mobile technologies that have invaded the lives of educators and students globally, it is clear that prospective students use mobile technology such as smart phones and tablets to research academic institutions where they want to further their studies. Current university students are "high users" of mobile phones (Cotton, 2008:59) and have different aptitudes and prospects than their predecessors of a few years ago because of the growing attractiveness of mobile devices. Research by Junco and Mastrodicasa (2007) and Lenhart, Madden and Hitlin (2005) shows that "students and young adults use a variety of technology at very high levels, much higher than other age groups in the United States" (Cotten, 2008, p. 56) and for a variety of purposes, for example email, surfing the Internet, texting and socialising (Quan-Haase, 2007). A survey, conducted by Salaway, Caruso and Nelson (2007) involving 103 institutions and 27,846 university students, reported that students spend, on average, 18 hours per week using the Internet in various capacities.

Students' expectations of the use of mobile technology in the classroom in higher education should be taken into account, and efforts should be made to engage students directly in a dialogue about how they would like to see their institutions use technology to help students learn more effectively (Roberts, 2004). The measurement of students' perceptions towards the use of mobile technology may be critical in establishing appropriate interventions to help lecturers integrate these resources into teaching and learning situations (Chao, 2005). The results may be useful in determining whether their experiences and perceptions warrant the development of teaching methods that make use of mobile devices.

\section{Purpose of this Study}

The purpose of this study was to identify computer science students' expectations of mobile technology in class.

\section{Research Methodology}

According to Zikmund, Babin, Carr and Griffin (2010), a quantitative research approach provides a quick, inexpensive, efficient and accurate means of accessing the desired information, thus this method was used to collect data for this study. An appropriate literature review on mobile technology as an educational aid was conducted. Arising from the literature review, a questionnaire was developed to investigate students' perceptions towards mobile technology in the classroom.

\subsection{Sample and Procedure}

University students are easily accessible; therefore, they constitute an attractive sample (Forgays, Hyman \& Schreiber, 2014). A non-probability convenience sample of 300 students from one university campus in the Gauteng province of South Africa formed part of this research. Participants were selected arbitrarily, irrespective of gender or race.

The researcher administered the questionnaire to the participants personally outside the lecture time of students.

\subsection{Research Instrument}

Following the literature review, a questionnaire was developed to identify students' perceptions of mobile technology in the classroom. The questionnaire used to collect data consisted of 33 items, which included questions on demographics and attitudes towards mobile technology in class. Except for the demographics, all items were scored on a five-point Likert-type scale, with one denoting strongly disagree, and five referring to strongly agree. 
The questionnaire was reviewed for content validity by two academics, one being an expert in mobile technology and the other in quantitative research. To ensure the reliability of the questionnaire, a pilot test was conducted on a convenience sample of 40 students. The reliability of the questionnaire was found to be 0.771 .

\subsection{Ethical Considerations}

The purpose of the study was explained to the participants and they were informed that their participation was voluntary, and of their right to anonymity and confidentiality They were also assured that the data collected and the information from the study would be reported in a cumulative format.

\subsection{Data Analysis}

The reliability of the data collected using the questionnaire was determined using Cronbach alpha. Frequencies were used to report on the results. The Statistical Package for the Social Sciences (SPSS - version 22) was used to analyse the data.

\section{Results}

\subsection{Demographics}

Of a total of 300 questionnaires which were distributed, 198 completed questionnaires (response rate $=66 \%$ ) were returned. The data revealed that the majority of respondents, 53.8 percent, were male and that 46.2 percent were female. 10.2 percent of the participants were first-year students, 48 percent in their second year, 32.1 percent in their third year and 9.7 percent in their fourth year of study. When asked whether the secondary school where they completed their grade 12 studies offered computer science as a subject, 64 percent of the respondents answered no, while 36 percent attended a school where computer science was offered. Respondents indicated that 47.7 percent had no computer science training before they came to university while 20.3 percent attended computer science up to grade 12 in secondary school.

Regarding ownership of mobile technology, 71.6 percent own a personal computer (PC), 77.2 percent own a laptop and 93.4 percent own a mobile phone. The minority, 19.3 percent, owns a tablet or an iPad.

\section{Discussion}

Table 1 illustrates the participants' perceptions towards the use of technology in class. For the purpose of discussion of Table 1 the scores for strongly agree and agree are combined, and agree and strongly agree are combined.

\subsection{Mobile technology in class}

Class time can be managed more efficiently as less time is wasted changing slides or writing on boards (Daniels, 1999; Mantei, 2000). The majority of participants (46.7\%) preferred a well prepared set of PowerPoint slides during a lecture rather than the use of mobile technology, while the minority (25.9\%) disagreed, and the rest were undecided. If participants were allowed to use mobile phones in class, the majority (58.6\%) was confident that mobile phones will not distract them from paying attention to the lecturer, but 43.9 percent felt that too much class time will be wasted if mobile devices were used in class. Contrary to this, the majority, 65.5 percent, of participants indicated that they would like to use mobile devices in class and 76.1 percent indicated that students should be allowed to gather information using mobile devices (for example, to access the Internet) in class. Despite this positive attitude, 42.6 percent indicated that they were not allowed to use mobile devices in class.

\subsection{Mobile technology in education}

Introducing mobile technology into the classroom may have a positive impact on students' perceptions of the course (Lavin, Korte \& Davies, 2009). There was a strong belief amongst the majority of participants (65.5\%) that mobile phones can play an important role in education, and 71.1 percent felt that lecturers should do more to facilitate the use of mobile devices in creative and meaningful ways. The use of technology in class adds to the credibility of the lecturer (Atkins- 
Sayre, Hopkins, Mohundro \& Sayre, 1998).

\subsection{Participation in class}

When asked if they were content to be inactive in class and in favor of the traditional model of teaching (wherein the lecturer is lecturing to students for a set period of time using traditional resources such as PowerPoint slides, a white board or textbooks), participants were fairly undecided (about 33\% disagreed, 33\% were neutral and 33\% agreed). Contrary to these neutral responses 86.8 percent indicated that they prefer to be actively involved in class, 72.1 percent indicated that students should be allowed to make video recordings in class (for example, of each other working out problems on the board with the purpose of posting the videos on blogs so that other students can watch them and learn). The majority (65\%) felt that students should be issued with a mobile device to be used in class.

\subsection{Effect of mobile technology}

Mobile devices were used extensively for academic purposes by 62.4 percent of the participants. 71 percent of the participants were of the opinion that the use of mobile devices in class will enhance their learning experience. Students were not sure that mobile devices in class will help to achieve the learning outcomes as only 54.3 percent indicated that they will. Only 50.2 percent felt that the use of a mobile device in class will motivate them to perform better, while the majority (61.4) felt that they will be better prepared for their career if mobile devices are used in class. In addition, 57.4 percent indicated that they will be better prepared for the workplace.

\subsection{Mobile technology preference}

Mobile technology may better support diverse needs and preferences of students (Lavin, Korte \& Davies, 2009). Participants were asked to comment on their preferences regarding which mobile devices to use during lectures. The reaction was not in favor of mobile phones in class as 42.2 percent are against it while only 39.1 percent voted in favour of it. Contrary to this, the majority, 73.6 percent, preferred to use tablets or iPads, while 69.6 percent indicated that they prefer laptops in class. 59.9 percent preferred to use their own mobile devices in class.

Table 1. Perceptions towards the use of technology in class

\begin{tabular}{|c|c|c|c|}
\hline Item & \begin{tabular}{|c|}
$\begin{array}{c}\text { Strongly disagree } \\
\text { / Disagree }\end{array}$ \\
\end{tabular} & $\begin{array}{c}\text { Neither agree } \\
\text { nor disagree }\end{array}$ & \begin{tabular}{|c|} 
Agree / \\
Strongly agree \\
\end{tabular} \\
\hline \multicolumn{4}{|l|}{ Mobile technology in class } \\
\hline $\begin{array}{l}\text { If the lecturer is using a well prepared set of PowerPoint slides, mobile devices are } \\
\text { unnecessary in class. }\end{array}$ & $25.9 \%$ & $27.4 \%$ & $46.7 \%$ \\
\hline $\begin{array}{l}\text { The use of mobile phones in class will distract me from paying attention to the } \\
\text { lecturer. }\end{array}$ & $58.6 \%$ & $17.7 \%$ & $23.7 \%$ \\
\hline The use of mobile devices in class will waste too much class time. & $23.3 \%$ & $32.8 \%$ & $43.9 \%$ \\
\hline At least one of my lecturers allows me to use a mobile device in class. & $42.6 \%$ & $20.3 \%$ & $37 \%$ \\
\hline I would like to use a mobile device in class. & $16.2 \%$ & $18.3 \%$ & $65.5 \%$ \\
\hline $\begin{array}{l}\text { Students should be allowed to gather information using mobile devices (for } \\
\text { example access the Internet) in class. }\end{array}$ & $10.7 \%$ & $13.2 \%$ & $76.1 \%$ \\
\hline \multicolumn{4}{|l|}{ Mobile technology in education } \\
\hline I believe that mobile phones can play an important role in education. & $18.3 \%$ & $16.2 \%$ & $65.5 \%$ \\
\hline $\begin{array}{l}\text { Lecturers should do more to facilitate use of mobile devices in creative and } \\
\text { meaningful ways. }\end{array}$ & $10.7 \%$ & $18.3 \%$ & $71.1 \%$ \\
\hline \multicolumn{4}{|l|}{ Participation in class } \\
\hline I am happy to just listen to the lecturer in class. & $36.1 \%$ & $32.5 \%$ & $31.4 \%$ \\
\hline $\begin{array}{l}\text { I am in favour of the traditional model of teaching (where the lecturer is lecturing to } \\
\text { students for a set period of time using traditional resources such as PowerPoint, } \\
\text { white board, textbook). }\end{array}$ & $33.5 \%$ & $28.9 \%$ & $37.6 \%$ \\
\hline I prefer a class where I am actively involved. & $2 \%$ & $11.2 \%$ & $86.8 \%$ \\
\hline $\begin{array}{l}\text { I would like to be part of a class where everybody uses a mobile device (for } \\
\text { example to search the web, complete assignments, etc.) }\end{array}$ & $11.2 \%$ & $21.3 \%$ & $69.5 \%$ \\
\hline
\end{tabular}




\begin{tabular}{|c|c|c|c|}
\hline $\begin{array}{l}\text { Students should be allowed to make video recordings in class (for example of each other working out } \\
\text { problems on the board and then post the videos on blogs so that other students can watch it and } \\
\text { learn). }\end{array}$ & $6.6 \%$ & $21.3 \%$ & $72.1 \%$ \\
\hline Students should be issued with a mobile device to be used in class. & $13.2 \%$ & $21.8 \%$ & $65 \%$ \\
\hline \multicolumn{4}{|l|}{ Effect of mobile technology } \\
\hline I use my own mobile device extensively for academic purposes. & $18.8 \%$ & $18.8 \%$ & $62.4 \%$ \\
\hline The use of a mobile device in class will enhance my learning experience. & $14.2 \%$ & $14.7 \%$ & $71 \%$ \\
\hline The use of a mobile device in class will help me achieve my academic outcomes. & $16.3 \%$ & $29.4 \%$ & $54.3 \%$ \\
\hline The use of a mobile device in class will motivate me to perform better. & $22.3 \%$ & $27.4 \%$ & $50.2 \%$ \\
\hline The use of a mobile device in class will prepare me better for my career. & $15.7 \%$ & $22.8 \%$ & $61.4 \%$ \\
\hline The use of a mobile device in class will prepare me for the workplace. & $14.2 \%$ & $28.4 \%$ & $57.4 \%$ \\
\hline \multicolumn{4}{|l|}{ Mobile technology preference } \\
\hline If all the learning material is available on a mobile device, I will prefer to use a mobile phone in class. & $42.2 \%$ & $18.8 \%$ & $39.1 \%$ \\
\hline If all the learning material is available on a mobile device, I will prefer to use a tablet or iPad in class. & $13.2 \%$ & $13.2 \%$ & $73.6 \%$ \\
\hline If all the learning material is available on a mobile device, I will prefer to use a laptop in class. & $15.2 \%$ & $15.2 \%$ & $69.6 \%$ \\
\hline If mobile devices are allowed in class I will prefer to bring my own device to class. & $17.3 \%$ & $22.8 \%$ & $59.9 \%$ \\
\hline
\end{tabular}

\section{Limitation and Implications for Further Research}

A non-probability convenience sampling method was used in a single province in South Africa and only at one university campus. The nature of the sampling method thus limited the study, and findings of the perceptions of students regarding the use of technology in class should not be generalised without caution. Notwithstanding this limitation, this study makes a significant contribution to existing knowledge regarding the perceptions of students towards mobile technology in the classroom.

Extending the study to a broader audience and comparing the results may provide a more comprehensive illustration of the perceptions of students towards the use of mobile technology in the classroom.

\section{Conclusion}

The purpose of this study was to investigate students' perceptions towards mobile technology in the classroom. The study revealed that students have a positive attitude towards the use of technology in the classroom. The majority indicated that there are potential benefits in using technology in class. It is clear from the results that laptops and tablets are preferred in class as there is a fairly negative response with regard to the use of mobile phones in class.

\section{References}

Atkins-Sayre, W., Hopkins, S., Mohundro, S., \& Sayre, W. (1998). Rewards and liabilities of presenting software as an ancillary tool: prison or paradise? Paper presented at the National Communication Association Eighty Fourth Annual Conference, New York, NY.

Chao, C. C. (2005). Evaluating teachers' attitudes towards the use of wireless-mobile technologies in supporting learning: an instrument development study. Proceedings of the IEEE International Workshop on Wireless and Mobile Technologies in Education (WMTE'2005).

Cotten, S. R. (2008). Students' technology use and the impacts on well-being. New directions for student services. Wiley Periodicals, Inc, 124, Winter, 55-70.

Daniels. (1999). Introducing technology in the classroom: PowerPoint as a first step. Journal of Computing in Higher education, 10, 4256.

Forgays, D. K., Hyman, I., \& Schreiber, J. (2014). Texting everywhere for everything: gender and age differences in cell phone etiquette and use. Computers in Human Behavior, 31, 314-321.

(March 22, 2014).

Johnson, P. (2012). Why mobile will transform learning: the classroom of the future. [Online] Available: http://spark.qualcomm.com/salon/Why-Mobile-Will-Transform-Learning-Classroom-Future (December 3, 2013).

Junco, R., \& Mastrodicasa, J. (2007). Connecting to the net generation. Washington, D.C.: National Association of Student Personnel Administrators.

Kurkovsky, S. (2009). Engaging students through mobile game development. ACM SIGCSE Bulletin, 41(1), 44-48.

Lavin, A. M., Korte, L., \& Davies, T. L. (2009). The impact of classroom technology on student behaviour. Journal of Technology Research, 1-13. [Online] Available: http://alcwynparker.co.uk/?p=244 (June 24, 2014).

Lenhart, A., Madden, M., \& Hitlin, P. (2005). Teens and technology: youth are leading the transition to a fully wired and mobile nation. 
Pew Internet and American Life Project. [Online] Available: http://www.pewinternet.org/ppf/r/162/report_display.asp (November 12, 2013)

Mantei, E. (2009). Using Internet class notes and PowerPoint in the physical geology lecture. Journal of College Science Teaching, 29, pp. 301-305.

PRWeb, (2013). [Online] Available: http://www.prweb.com/releases/2013/7/prweb10927255.htm (July 18, 2014).

Quan-Haase, A. 2007. College students' local and distance communications: blending online and offline media. Information, Communication and Society, 10, 671-693.

Resnick, M., Maloney, J., Hernández, A. M., Rusk, N., Eastmond, E., Brennan, K., Millner, A., Rosenbaum, E., Silver, J., Silverman, B., \& Kafai, Y. (2009). Scratch: programming for all, Communications of the ACM, 52(11), 60-67.

Roberts, G. R. (2004). Technology and learning expectations of the net generation. [Online] Available: http://www.educause.edu/research-and-publications/books/educating-net-generation/technology-and-learning-expectations-netgeneration (December 3, 2013).

Rodgers, W. (2014). Technology in the classroom. [Online] Available: http://www.shelbyed.k12.al.us/schools/rms/faculty/wrodgers /technology\%2 0int/students.html (January 15, 2014).

Salaway, G., Caruso, J. B., \& Nelson, M. R. (2007). The ECAR study of undergraduate students and information technology. Boulder, Colo.: EDUCASE. [Online] Available: http://connect.educase.edu/library/abstract/TheECARStufyofUnderg/45075 (June 26, 2013).

Seng, J. (2013). Smartphones allowed in school's WE Learn project. [Online] Available: http://asia.cnet.com/smartphones-allowed-inschools-we-learn-project-62221288.htm (April 14, 2014).

Stables, K. (1997). Critical issues to consider when introducing technology education into the curriculum of young learners. Journal of Technology Education, 8(2), Spring.

Zikmund, W. G., Babin, B. J., Carr, J. C., \& Griffin, M. (2010). Business research methods. (8th ed.). Southern-Western: Cengage Learning. 